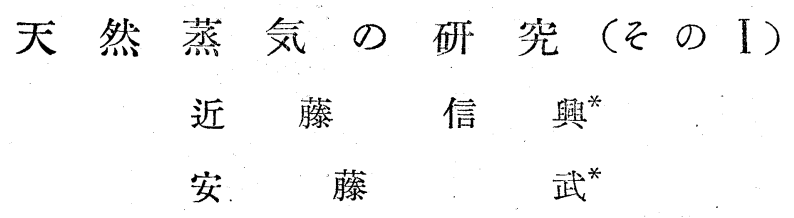

\title{
Study on the Natural Steam in Japan
}

By

S. Kondō and T. Andō

(Résumé)

In this paper the authors explained theoretically the existence of natural steam uncier the ground and examined whether our theory practically agree with the present field data or not. We got many interesting results in this research, and natural steam in Japan may be able to utilize for electrification in the near future.

\section{1. 緒言}

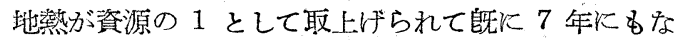
り，その間に調查目的の呀孔がぞれだけ行われたかを顧 又ると，未だ僅かに 2 本に過ぎない。ロでこそ地熱は掘

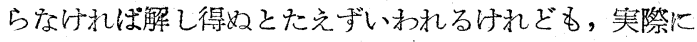
行らのは易くないことかくの如くである。しかしその途 の專門家までが，掘らなければ解らないといつたのでは 調查涪障が起るであらら。ここを掘るならば必らず高 温・高圧の蒸気が得られ、その範囲はこれこれであると 指示できるよらな研究ができたならば，われれれの役 目は果し得たということができる。従つて掘つて見るこ とに勝るものはないが，な扔その上に掘つた記錄によつ て，未だ掘らない所の地域の見透しを充分つけることが われわれの仕事で安り，望なしい。

それがためには今までに掘つた記錄を最大に活用し て，その第孔附近の墸条件とにら久併せて特徵を捕光， そして逆に特性なり諸条件を満足せしめるためには，地 下がかくの如くでなければなら奴いう結論を出すこと ができるならば，いちいち掘つて見なくてもすむだけに その効果は大きいものが女る。本邦に怙ける地熱地は， 分散するために規模が小さいように見えるけれども，こ れ等を総計したすのは決してもなどり難いすのがあり， たた邊憾なことには，個々の地熱地について呤味する方 法の研究ができていない。本研究はわれわれによつて行 われた調查資料と，同友諸兄の研究とを基にして得た新 しい考え方と見方の一端で女つて, 相当先走つているが， 方法の破究として少しでも役立てば望外の幸で女る。

* 地筫謂查所地筫部 地学嚾誌 Vol. 62 No. 2 (688) 1953

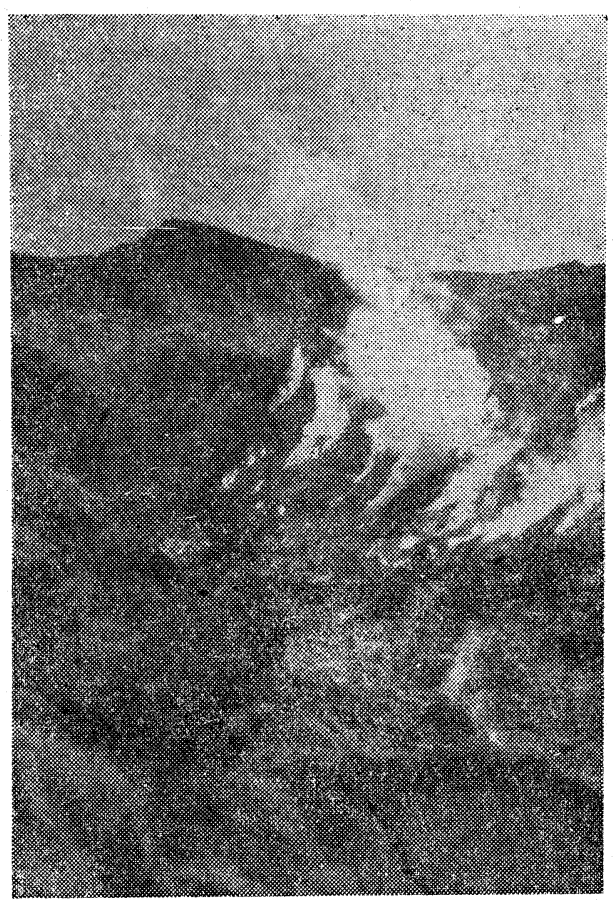

(加々美氏撮映)

兀重山地蓺地亚の噴煙の遠望 蒸気の露頭50数個所のむ主要噴気孔は10数個所 あり，硫化水素の穓気が 6 粁先に屯で達する。

\section{2. 地熱地帶表面の特性}

地龿地帶として今までに見た中で强大と思われるすの を挙泞ると，次の如くであつて，われれれは特炕こ等 を本邦 12 の大地熱地と哷んでいる。

\section{（1）硫黄山（跡佐登，北海道）}


(2) 登 別 (北海道)

(3) 恐 山（青森）

(4) 墝山（八幡平，秋田）

(5) 荒雄岳 (宮城)

（6）箱根山（大涌谷, 神奈川)

(7) 立山 (富山)

（8）別府（大分）

（9）九重山（大潩，大分)

(10) 雲仙岳 (長崎)

（11）阿蘇山（湯の谷, 垂玉, 熊本）

（12）霧島山（鹿兒島）

見掛上替模の小さいるのはごのほかる多数あり，今 後の調查の結果いかんではこの列に加わるものが出てく

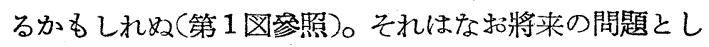
て殘して扣き，以上が大体わが国に招ける地熱開発の対 象となるものである。

これ等の地域を現地において見ると，特に共通した点 が多数ある。

（1）地蓺地帶は最近まで活動したいわゆる活火山に 極めて接近して賦存している。

（2）天然蒸気の噴出地域にはある範囲があつて，こ れを越えると露頭はすちろん地温すなくなる。

(3) 蒸気帶一面には必らず広い燒けを生じて扣り，。 その畓けは珪酸質白土から成る。

（4）珪酸質白土の分布地域加ら出ている蒸気の露頭 は，大小種々で一定しないけれども，少なくとも 1,2 ケ 所には乾燥蒸気を出している活ど强烈なるのがある。
（5）强烈な噴気の上を川の流孔が通過している所で は,川水は盛んに踊つている割合に水は高温となつてい ない。

（6）これ等の蒸気帶の外側，すなわち蒸気帶をやや 離れると，湯帶があつて温泉地をなしている。

以上は重要な共通事実であつて, 以下述べる理論と一 致するならば，新しい地熱地帶に出会つた時にも，この 理論を基にしてその地帶を解くことができるであろろ。

第 1 図

本邦に和ける地熱地の分布図

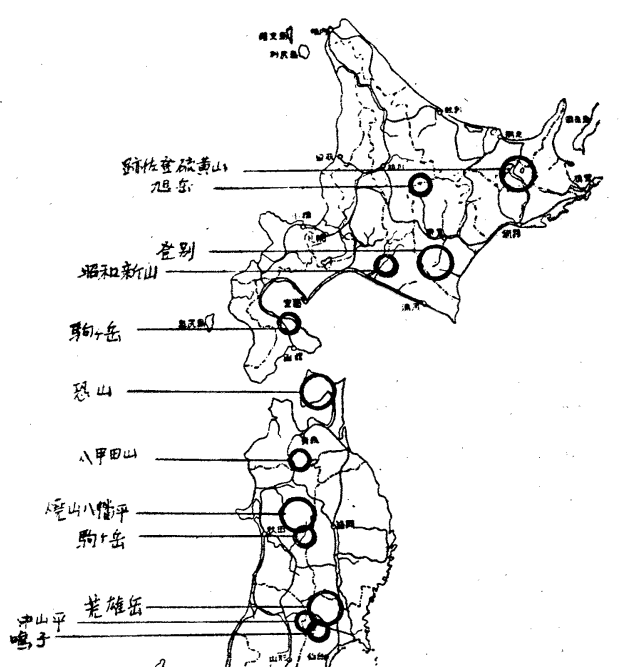

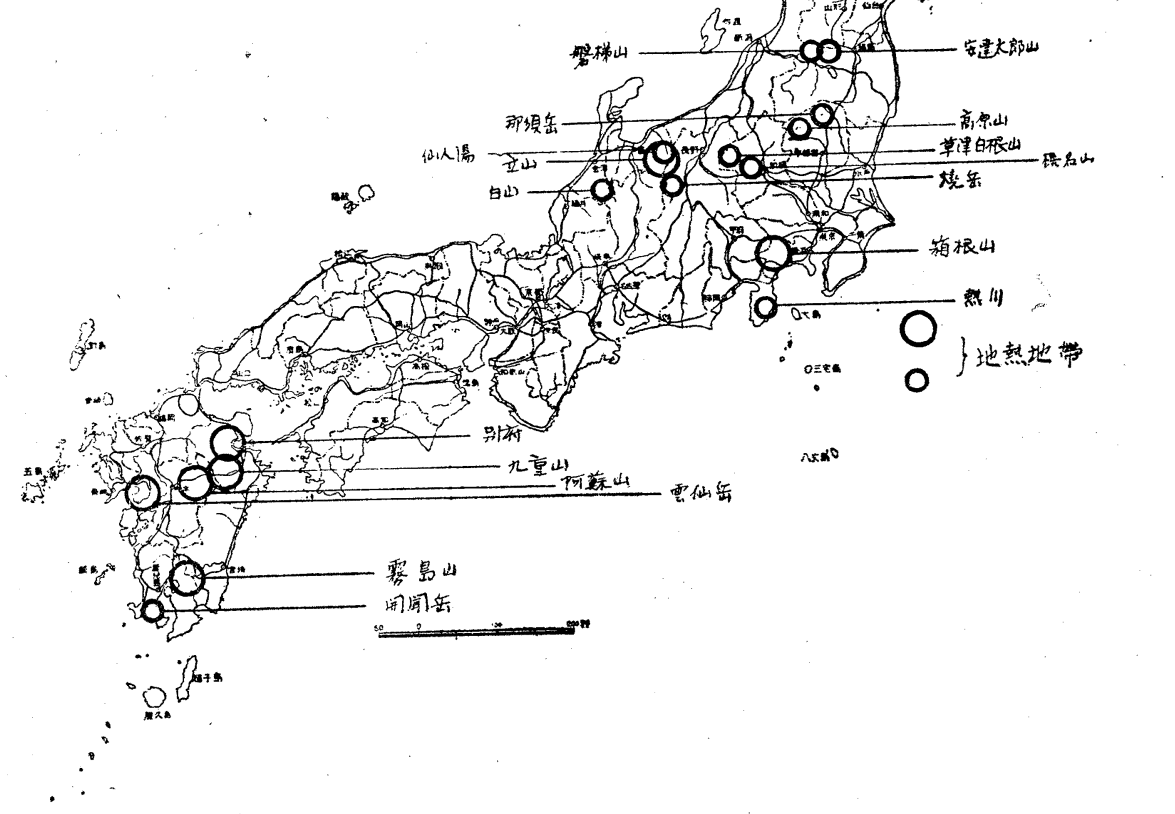




\section{3. 地熱地帶穿孔の溫庋}

第 2 図は地質調查所が地熱調查のためK，特にボーリ ングを試みつつ孔內を笑測した温度である。それによれ ば, 地表に扔いて既火地温は気温よりも高く, 大体 $30^{\circ} \mathrm{C}$ 內外を有し，これを直下以掘進寸れば地䰻は順次上昇 し，その温度公配は地熱地帶固有の公配で上昇するので あるが，その勾配は相当急であり，また高地熱地ほどい よいよ急となることが推定される。

第 2 図調 查孔 湘 溫図
A 大分具別府白童
B 大分県野矢

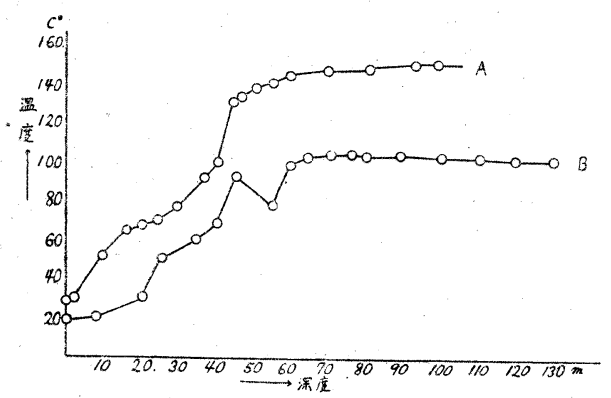

さらに掘り進めると, 今までの地温勾配は $100^{\circ}$ あ いはそれ以上のところぬで保持されるが，ある樑さまで 達するとそれ以上勾配を有し得ない点に達する。その点 から先は温度勾配がぐつと䌅かになり，これが長く続い てゆく。第2図は土地固有の地温を現わしているけれど む, 勾配の形は全くよく似ている。これがすなわち地熱 地帶の深度と地温との間に招ける特性ともいいろる。

\section{4. 地下水帶と蒸気帶の存在}

奥田氏は第 2 区 $A$ の地温曲線に対して, 次の如き理諭 を提唱し発表している。

『地熱地域の中心部の地表に近い部分では，爇の流れ は地表に直角方向に平行であると考えるから，地質が一 様であると仮定すれば，地下水帶に㧊ける温度勾配は第

第 3 図地下に招ける天然蒸気の温度と圧力

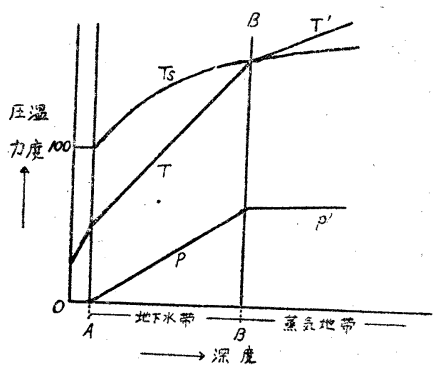

3 図Tの如く直線的である筈である。ただし $O$ は地表,

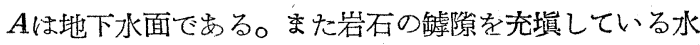
の匠力は，水の流動の影響を無視すればほぼ静生に等し く，從て同図 $P$ の如く直線的になるはずである。次に $T_{\boldsymbol{s}}$ 曲線は $P$ なる圧力K相当する飽和蒸気の温度であ る。もし $T$ が $T s$ 曲線と $B$ 点に特いて交はる場合に は， $B$ 点より染い地点では水でなく蒸気が存在しなけ ればならない。從て $B$ は水と蒸気との境界面である。

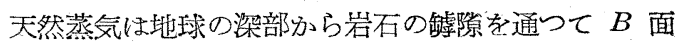
まで上昇し，ここで㠜結して潜熱を発生し，その熱が伝 薄によつて地表に伝わるのであるから，蒸気地帶の温度 を $T^{\prime}$ とする時, $B$ 点附近に特いて $T^{\prime}$ 曲線の傾は $T$ 曲線のそれよりも遥かに小でなければならない。しかし $T^{\prime}$ 曲線は $T s$ 曲線の延長よりも下Kくることは許され ない。

また蒸気帶の生力 $P^{\prime}$ Kついて考えるに，岩石の鐻隌 の程度にもよるけれども，蒸気の流れは一般に極めて緩 かであるから， $P^{\prime}$ 曲線の傾は非常に小であると考えら れる。從つて天然蒸気は地球の燃部では過熱蒸気であつ て，それが次第に冷されつり上昇し， $B$ 面に達した時 初めて飽和蒸気になるすのと考えられる。d

第2 2 加ら以上の事柄を要約すると, 学特定の地熱 地域の地下には地下水帶と蒸気帶が存在し, この両者は 女る適当な温度怙よび圧力のもとに扣いて, 平衡が保持 されているとの考方方岕る。

\section{5. 地下水帶と蒸気帶との平衡関係}

第 4 図に招いて無水帶，地下水帶と蒸気帶の女るよう な理想断面を考学る。そして $P$ 点を地下水帶と蒸気帶

第 4 図 地下水帶と蒸気带の存在を表わす図

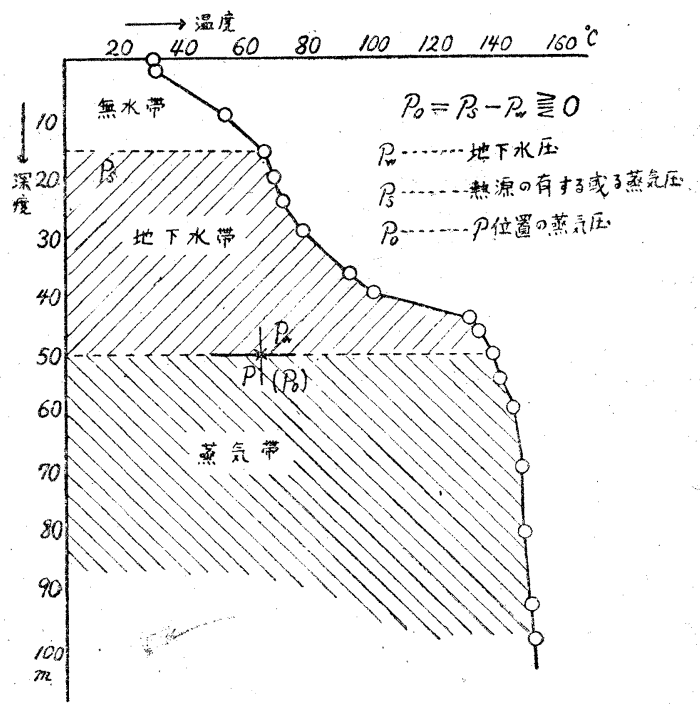


との艾わりの 1 点とし, その点の地下水生を $P_{w}$, 蒸気 圧学 $P_{0}$, 熱源の有与る古蒸気圧を $P_{s}$ として, 水と 蒸気の圷力損失索無視すると， $P_{o}=P_{s}-P_{w}=0$ となり， 気水界面は活とえど上下に移動すること分ない。るし水

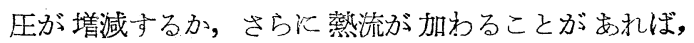
$P_{s}-P_{w} \gtrless 0$ となり, 気水界面は段及下上昇してゆく場 合と，深い所へ降つてゆく場合とが考㝋られる。

熱源为遥加遠いところに岕る場合や，熱源そのもの が莯に弱つている場合には，熱の流れが極めて緩曼であ るから， $P_{s}-P_{w}=0$ は成立つが，活火山のような高温・ 高圧の熱源が近くK宓つて，これからの充分な禣給の通 路をもつているような場合には，Ps り得ないであろろ。從て $P_{s}-P_{w}$ は零より大となるか ら，P点は地表晌つて段々比界する。そして一度 上昇が始まると，今までの平衡は破水，気水界面はとめ ぞもなく上昇し，地下水が流動して新たにこれを冷さな い限り, 水は沸膫上昇し, 地下水下の蒸気は無水帶をむ通 過して空中に自由に放出さ和るに至る。その場合には気 水界面が地下Kはなくなり，地上すなるち空中高い所に 存在することとなる。天然の噴気孔または地獄はこれで めつて，火山の爆裂はその極端なるのである。をた噴気 孔に水学注大して溜めると，湔䐋した湯ができる。これ を人工温泉として利用しているのを見るがここには人 工気水界面を見ることができる。

以上の場合と全く逆のことも考光うる。下からの熱の 補給上りも地下水生が高くなつて, 熱の吸收の方が遥か 火著しい場合には, $P_{s}-P_{w}<0$ であるから, 気水界面は 段及飞降下し，高温の湯ばかりとなるであるう。 $100^{\circ} \mathrm{C}$ あるいはそれ以上の高温泉が, 谷間の两岸相迫つた河床 Кしばしば発自せられたり，海岸の温泉が蒸気交りであ つたりするのは，この理由によるるのである。

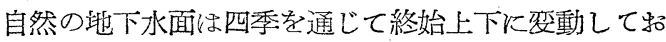
り，蒸気る流れているから，地中に気水界面があること は一応理論的火成立しても，突際には相当不安定なるの であって，地上噴気を作るか，さもなければ湯帶だけ となるか，いずれかの安定方向へ天然では落付く傾向が 大である。

\section{6. 地中に気水界面がある場合の穿孔}

第5困火执、て,無水帶が地下 $15 \mathrm{~m}$, 地下水帶がそれ から50 m まであるとし,それ以下は蒸気帶にはいるよろ な地蓺地帶があると仮定する。今艺の $A$ 点炕穿孔すると すれば，孔が僅か炏進しだ時水は割目を透して逃げ始 め，その範团を $A A^{\prime}$ とすれば，掘進が $B$ 点に達した 時は, 空腺が均一で女る限り, 水圧増加に上り逃水範囲

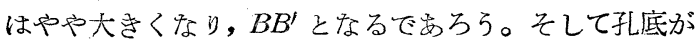

第 5 図 地下水䐭と蒸気帶の中を穿孔す る場合の図解

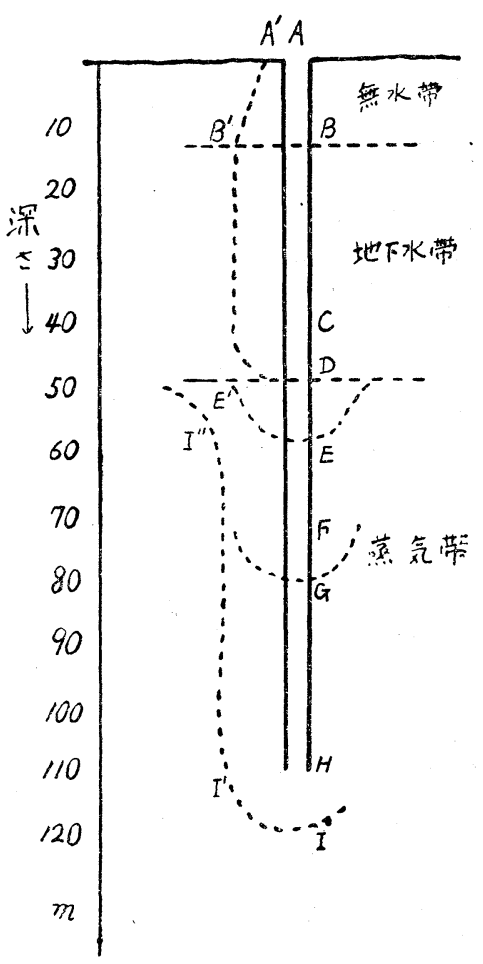

$B$ 点を過ざる頃からは，地下水圧の抵抗力澵たに加わる から， $B$ 点から先の逃水範囲はほ㴗均等とな $り C$ 点ま で続くで女ろろ。孔底が $C$ 点に届いた時，逃水箢团は 気水界面 $D$ 亿遭遇し, 蒸気和新しい水で冷却され, 蒸 気の㠜結が起り湯を生じ始める。その場合気水界面は, 無水帶の厚さK相当する水圧を今をでの水圧より余計に 受汓ることとなり，水の蒸発より蒸気の㠜結の方が盛ん であるから，界面は降下せざるを得なくなるであろう。 哿孔があつと進むと界面はさらに降下し，元の界面 $D$ K 孔底か椡達した時住, 界面は既に逃げ去つて $E$ 点に まで降つているであらろ。さらに穿孔を続け, 孔底が $F$ 点に達した時は, 界面の位置は $G$ Kまで降下寸る。從 て孔底はどこまで掘進しても界面火出逢つことは山り得 ない。そして孔底が逐に $H$ 点 $(110 \mathrm{~m})$ 飞達した時に は，同様な理由によつて気水界面は特よそI I' I' の如 き形狀となることが想像せられる。ただしIIII'は新 規の界面上の点である。孔底が $D$ K達してから $H$ K 至るまでの間は，既爅気帶に乫入しているはずである

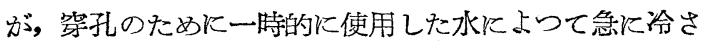
れるから, $D$ の温度よりる $I$ の温度の方が高くはなつて 扣り，水の蒸発々蒸気の㠜結は烈しくなつているはずで 出る。今この孔の掘進のため使用した水を, 掘作終了 
後も逃げないるのとして常に一杯保ち放置したとすれ ば，孔底附近の界面に招いて初めて蒸気の㠜結が盛えで めつて子，水の交流がないから，途中から水の蒸発の方 が盛んになつて，次第に元の安定な方向に気化作用が起 $\eta ，$ 長期の時間的経過の後には，H, $G, F, E$ 飞る飞蒸

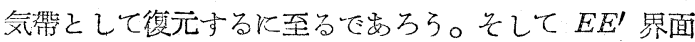
で最も安定等状態となるはずである。この場合では 110

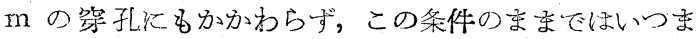
で放蛔しても蒸気の噴出安見ることは娄り得ない。る乙 この呀孔火和いて蒸気を孔口から出すためには， $E$ 点ま で鉄管を插入して，側壁からの水の浸入を防ぎ，孔內の 水完完全排除する場合に限る。しかも出てくる蒸気は 湯の冷却と同程度の熱の䋠給力しが持つていないから温 度も圧力低い众点がある。そして5節の終りに述べた よう火地中の界面は不安定であるから，呀孔に便用した 水のため冷されて湯となることが多いであるう。

\section{7. 蒸氣帶が地上に露出する場合の穿孔}

第 5 困とその說明は，当初地下に蒸気燕が存在するも のと仮定して論を進めたのであるが，笑をいえば，これ は別府白龍試験孔の調查の結果であつて，110 m 孔底掘 作終了後, 2 週間放置して抢いたら爆発を起し，孔內の 泥水を全部獖上げて後，强力新蘚な蒸気噴出学見たので ある。水を入れたます放置しては，理論上蒸気噴出を見

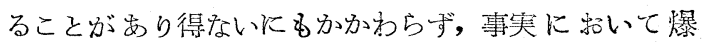
発・噴出したとすれば，雨者のどこが矛盾が存在す る。すなおら放置した気水界面が $E E^{\prime}$ 飞安定しないで, さらに $D, C, B, A$ と上昇しきたつたのであるから， 界面は地中を通過し，地上すなわち空中年つたことが 解せられる。このことは5節の中ほど述べたことと全

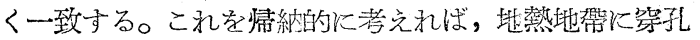

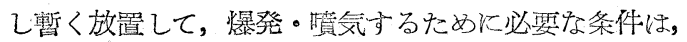

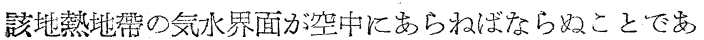
つて，か方る地蓺地帶の地下はすべて蒸気帶であるとい

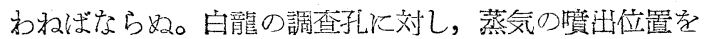
实測した山本氏の発表結果第1表の蜘くであつて，こ

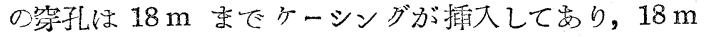
から $30 \mathrm{~m}$ までの約 $12 \mathrm{~m}$ の厚さは帽子岩をなすが，殘

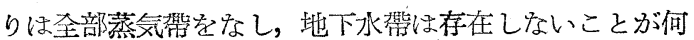
よりの立钲で劣る。理論的に出された界面 $D$ は天然の 界面ではなくて，呀孔使用した水と天然蒸気との間で できたいわゆる人工気水界面であつて，真のあるいは天 然の界面は地上飞岀ることが解妨られる。蒸気が非下水 を沸傰せしめ,総べて蒸気帶となれる所は, 蒸気圧力が高 いからその深、所を呀孔すれぱ爆発・憤気し，優樊なる 蒸気をるることとなる。これと反封に界面が地中に专る
よろな場合は，再度繰返すととになるが，樊源が遥かに 遠いか，微弱である場合火限り成立ら，水子蒸気の流動 が烈しい場合は不安定であって，天然には地中に招いて 上下K地下水々蒸気が重なるよろな界面が存在する場合 がありらるかどらか相当疑方しい。

第 1 表 白龍調查孔内に和汀る蒸気噴出位置 （実測者山本氏）

\begin{tabular}{|c|c|c|c|c|c|c|c|c|c|}
\hline $\begin{array}{l}\text { 樑度 } \\
(\mathrm{m}) \\
\end{array}$ & 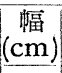 & "I & 11 & I" & "I & " & 11 & "I & "I \\
\hline 31.38 & 1.0 & 39.82 & 4 & 45.30 & 4 & 63.30 & 1 & 67.95 & 3 \\
\hline 32.03 & 1 & 39.90 & 0 & 47.35 & 7 & 63.47 & 5 & 70.60 & 0 \\
\hline 32.27 & 0 & 39.93 & 14 & 50.28 & 10 & 65.39 & 6 & 70.89 & 6 \\
\hline 32.31 & 8 & 40.25 & 0 & 52.00 & 10 & 65.86 & 1 & 71.30 & 3 \\
\hline 33.25 & 5 & 40.32 & 0 & 54.75 & 5 & 65.96 & 6 & 71.39 & 0 \\
\hline 33.72 & 0 & 40.76 & 0 & 55.70 & 1 & 66.07 & 6 & 71.51 & 4 \\
\hline 33.98 & 0 & 41.25 & 0 & 56.10 & 4 & 66.19 & 10 & 71.84 & 3 \\
\hline 34.11 & 0 & 41.66 & 8 & 57.41 & 7 & 66.34 & 3 & 71.98 & 2 \\
\hline 34.31 & 8 & 42.27 & 0 & 57.77 & 10 & 66.77 & 11 & 72.59 & 15 \\
\hline 35.00 & 1 & 42.47 & 6 & 58.13 & 2 & 66.90 & 3 & & \\
\hline 37.52 & 7 & 42.72 & 3 & 58.36 & 7 & 66.93 & 7 & & \\
\hline 37.97 & 8 & 42.86 & 2 & 58.72 & 9 & 67.15 & 5 & & \\
\hline 39.09 & 0 & 43.75 & 1 & 59.37 & .4 & 67.32 & 2 & & \\
\hline
\end{tabular}

伊太利ラルデレロの地熱地帶には帽子岩があつて，そ の下部蒸気が培積されているから强力蒸気であるとい われ，それ火引換光，目本の天然蒸気は浅い所火㟧つて 筒抜けで岁るから見达火乏しいという者るあるけれど も，筆者は決してそろは思はない。交献に上れば伊太利 でも蒸気露頭は無数にあり，明ら加に界面が空中に岕る ことを示して，地下水帶は蒸気帶と化している。ただこ の蒸気帶が $200 \mathrm{~km}^{2}$ に亘るといら漠大な面積の中にあ るから膨大な蒸気帶である。蒸気量が蒸気帶の広さとよ ることはもちろんである。しかし三土氏の旅行談によれ ば，伊太利の例でも500〜800 m 子掘つてな牤爆発も起 さずっケーシングを大れて中の水を排除すると，蒸気の噴 出を見た例の岁ることを考劣ると，露出蒸気带のほかに 埋沒蒸気帶のあることも事実である。これを図解すれば 第6図であつて，問題火なるのは断面火数ける気水界面

第 6 图蒸気带炕扔ける気水界面と 粗珪石の関保

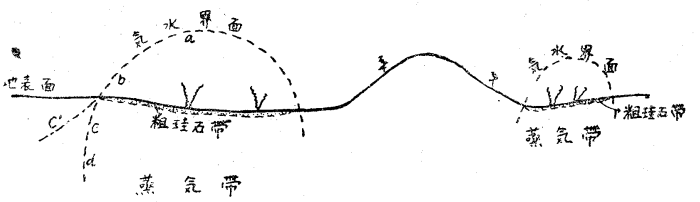

の形である。界面は図の $a b c^{\prime}$ の如き延長方向には取り 得ない。もし取り万るとすれば，呀孔後地下水圧上りも 蒸気压の方が早く堌大寸るから爆発を起し，そこは空中 界面とならなければなら奴らである。從て界面は $a b$ $c$ の方向を取らざるを得なく, 界面の形は $a b c d$ の 
如くなるのではないかと考えられるが，この問題は現在 の地形・熱流・地下水・割目の方向その他との複雜な関 係て簡單でないからな注今後の研究に待た㸚ばなら ぬ。こと露出蒸気帶が相隣つて並ぶことが天然にはし ばしばあり，両者の地下に招ける関係がどうなつている かを見ることは興味ある問題である。

日本の地熱地帶はその多くが散慢している久点はある が，それでも霛島山の如きはラルデレロと決して劣るる のではないと思われる。ただ買憾なのは調查の資料が ないだけである。目下地質調查所飞批いて調查破究中 であるから，そのうち成果は挙げられるであろらと思 万。

\section{8. 露出蒸氣帶における露頭岩石の研究}

こっにいら蒸気帶は地下埋没下の蒸気帶ではなくて, 地下水帶が全域気化した露出蒸気帶のことである。第 7 節の考党方では, 蒸気帶が露出する所では深、等孔によ り有望なる蒸気が得られるから，結局地上K怙ける蒸気 帶の形と，その断面が重要となることを述べた。また第 2 節に扣いて，天然蒸気の露頭のある場所飞はある範囲 があり，からその地域限つて露出する岩石は著しい燒 けを生じて秥り，橈けの岩石は珪酸質白土であるとの事 実を挙げた。今燒け石の分析結果を挙げると第 2 表の如 くである。

第 2 表 粗珪石（珪酸質白土）和よび粘土の成分（分析者安藤）

\begin{tabular}{|c|c|c|c|c|c|c|c|c|}
\hline & $\begin{array}{c}1 \\
\text { 粗 珪 石 }\end{array}$ & 粗珪石 & $\begin{array}{c}3 \\
\text { 粗珪石 }\end{array}$ & $\begin{array}{c}4 \\
\text { 白色粘土 }\end{array}$ & $\begin{array}{c}5 \\
\text { 白色粘土 }\end{array}$ & $\begin{array}{c}6 \\
\text { 粗 珪 石 }\end{array}$ & $\begin{array}{c}7 \\
\text { 靑黑粘土 }\end{array}$ & $7^{\prime}$ \\
\hline $\mathrm{Si} \mathrm{O}_{2}$ & 90.63 & 92.75 & 90.96 & 59.16 & 50.14 & 91.42 & 47.26 & 55.0 \\
\hline $\mathrm{Al}_{2} \mathrm{O}_{3}$ & 1.71 & 2.40 & 3.82 & 25.95 & 27.12 & 3.23 & 23.22 & 27.0 \\
\hline $\mathrm{Fe}_{2} \mathrm{O}_{3}$ & 0.62 & 0.30 & $\operatorname{tr}$ & 2.26 & 2.02 & - & - & \\
\hline $\mathrm{Ti} \mathrm{O}_{2}$ & 1.30 & 0.57 & n.d & 1.00 & 1.51 & n.d & n.d & \\
\hline $\mathrm{Mg} \mathrm{O}$ & 0.12 & $\operatorname{tr}$ & 0.04 & $\operatorname{tr}$ & $\operatorname{tr}$ & $\operatorname{tr}$ & 1.04 & 1.2 \\
\hline $\mathrm{CaO}$ & 0.08 & 0.10 & 0.04 & 0.06 & 1.16 & $\operatorname{tr}$ & $\operatorname{tr}$ & $\operatorname{tr}$ \\
\hline $\mathrm{H}_{2} \mathrm{O}+$ & - & - & - & - & - & 2.67 & 9.35 & 10.9 \\
\hline $\operatorname{Ig}_{2}$ loss & 2.18 & 2.88 & 3.23 & 10.10 & 16.21 & - & - & \\
\hline $\mathrm{H}_{2} \mathrm{O}-$ & 3.01 & 0.76 & 2.14 & 0.95 & 1.16 & 1.54 & 4.62 & 5.4 \\
\hline $\mathrm{Fe}$ & - & $\longrightarrow$ & $\operatorname{tr}$ & $\longrightarrow$ & - & 0.15 & 6.57 & \\
\hline $\mathrm{S}$ & - & - & 0.10 & $\longrightarrow$ & - & 0.21 & 7.48 & \\
\hline total & 99.65 & 99.76 & 100.33 & 99.48 & 99.32 & 99.22 & 99.54 & \\
\hline 遊離 珪酸 & 88.7 & 90.0 & 86.5 & 28.7 & 18.3 & 87.6 & & 23.2 \\
\hline
\end{tabular}

試料
No. 1 秋田縣鹿角郡宮川村, 後生掛 I
No. 2
No. 3
11
" " I I
No. 4
宮城縣玉造郡鬼首村, 荒雄䱋
No. 5
鹿兒島縣姶良郡牧園町, 鳥地猫
No. 6
" 栗野町, 栗野獾,
神奈川県足柄下郡仙石原村, 大涌谷

No. 7

\footnotetext{
"l

"l

"l
}

備考

1. 室内で自然乾燥を行つを試料について分析す

2. 遊離珪酸…..攀土はカオリナイトとして含まれるものとし，遊離珪酸量を無水物の形で表わした％

3. No. $7^{\prime}$ はNo. 7 より鉱染している硫化鉄を除いて換算したるの 
すなわちこの熱けは水を含さと粘りを生ずるから粘土 と誤認されるが，実際の粘土分は少なく，ほとんど珪酸 よりなつている。そして蒸気が强いほど顯著である。そ の外観は丁度揘き足りない招餅の如く，がさがさの表面 在有することも安り，全くチョークと同様火見えること あある。これは土と乎ばれるものではなく 1 種の岩石で ある。珪酸質白土と称するには何加物足りなく, 珪石と 呼ぶには耐火材・セヌント原料材と混同してな招さら不 都合である。さりとて適当な岩石名も見当らないため， 一応粗珪石と乎ぶこと〉した。それは密珪石に対する名 称で, 温泉の沈澱物である珪華を密珪石と呼ぶことがで きるならば，天然蒸気申の主として硫化水素の作用によ つて分解せられ，殘留した珪酸は粗珪石と呼ぶことが当 然と考えたからである。

天然蒸気が硫化水素を多く含有していることは周知の ことで，これが地表近くに達し，酸素と反応して硫酸と なり，周囲の岩石に作用してカオリン化を行い，アルカ リ・石灰・苦土・鉄等の硫酸塩を生じつつ流失し，さら に作用すると，アルミナまです硫酸塩として消失するに 至るから，跡には主として珪酸が殘る。すしこれが湯の 場合には硫化水素を含さこと極めて少なく，硫酸を生ず ることる少ないから, 岩石の分解も著しくはない。粗珪 石は天然蒸気作用の複甡物といらことができる。

粗珪石は强烈な蒸気帶にのみ生ずるるのなれば，これ が賦存する範囲はすなおら蒸気がかつて噴出していた所 であり，から現在もな叔そのどこかに噴出し粗珪石を作 りつ১あるならば，その範国はすなわら蒸気帶の露出範 囲である。地上に扣いて蒸気帶を捕捉するには，粗珪石 の賦存していること〉現在もな技噴気が見られつつある ことが，最も重要な条件である。第 7 ・8 図は鹿兒島県

第 7 図 鹿兒島県栗野岳地熱地帶 粗珪石和よび地溫分布図

(昭和 27 年 9 月調查 中村久由・安藤武)

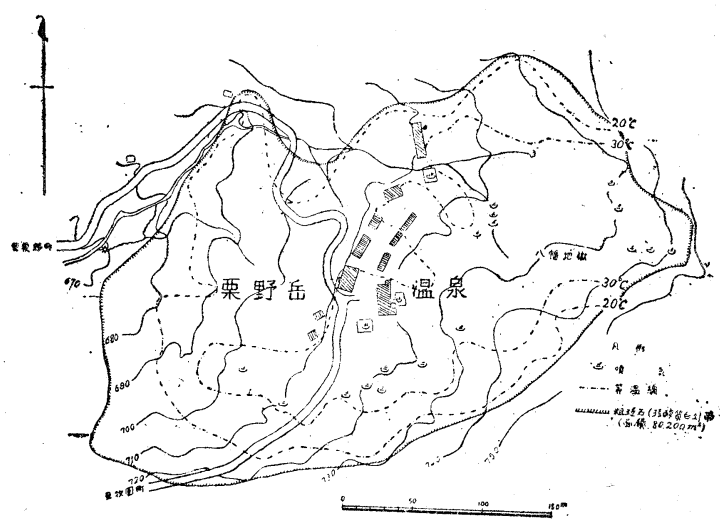

第 8 図 秋田県燒山（後生掛地域）地熱地帶 粗珪石和よび地溫分布図

(昭和 27 年10月調查 中村久由・安藤武)

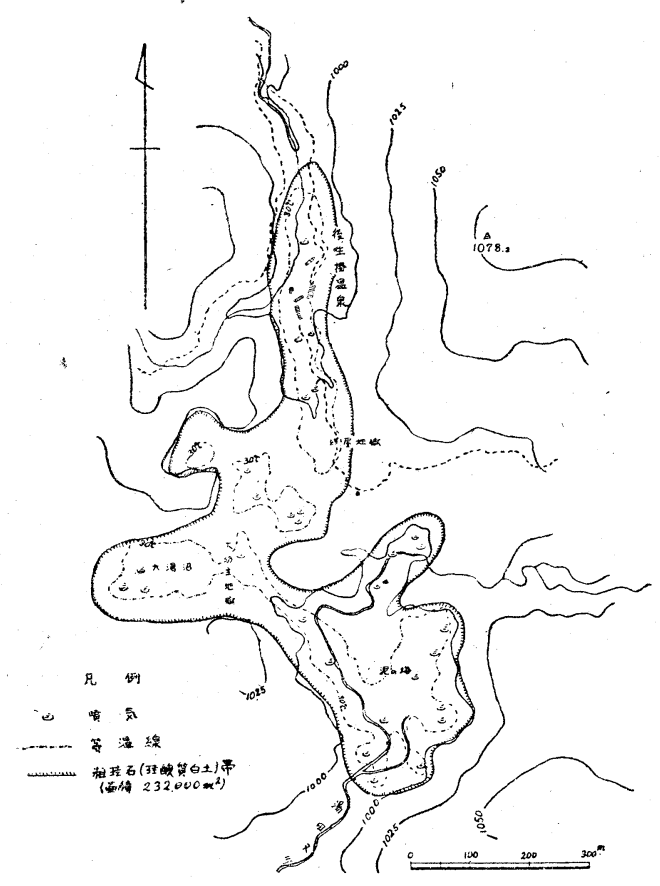

栗野岳地蕉地と, 秋田県後生掛地龿地の露出蒸気帶の形 状であつて, 現在の蒸気露頭と等温度線も記入して扣い た。後生掛の場合は蒸気帶が非常に不規則な輪廓を示し ている。これは地下水帶の形が地形に著しく支配せら れ，蒸気帶は地下水帶の水纴に影響せられるため不規則 形となつたものである。これ等の地熱地に扣いて呀孔す れば，必らず出る所の範䧃は大体了解されたと思らが， な和詳細な点に関しては紙数の都合上头回に讓る。

\section{9. 完全不透氣層下の蒸氣帶}

気水界面が空中にありながら，地中の岩石がいわゆる 1 枚岩盤のため完全不透気畨をなし，蒸気の露頭も何の 徵候もないところの埋沒蒸気帶が，まりはしないかとい 5 問題が女る。これは崖盤の支持力と蒸気帶內部の圧力 の比較であつて, も乙蒸気圧が强ければ装裂を起し, 大穴 があいて新しく地熱地ができる。なた岩盤の支持力が强 くてささえることができて, 埋沒蒸気帶が地下に存在し ても，それにば鳴動を伴うとか, 地温が高くなるとか,な ん等かの徵候がなければならないはずである。わが国の 如き褶曲と断層でできた国は，地表下数 $\mathrm{km}$ または10数 $\mathrm{km}$ ※で割目が存在することは，少しる不思議ではあり 得ない。從てかくれた强力な蒸気帶を期待することは㕅 
難なことであるといらよりは，実在し得ないという方が 確実性が多い。宛なき探しをするよりも，强力に噴出し ている現在の蒸気を有効に活用することこそ, 目下の急 務であると考学る。

\section{0. 結論}

地熱地帶の地下には，理論上地下水尖と蒸気帶とが存 在すると考兄られる。しかし実際には高温地熱地域の内 側は，既に蒸気帶と化して地下水帶は存在し得ない。 地蓺地帶が非地蓺地帶にろつり変る僅かの地域には, 地下水帶と蒸気帶が上下K重なつて存在する所がある。

地下水帶と蒸気帶の存在する場合, 两者の界面は相当 不安定であつて, 蒸気帶と化するか湯帶となるかいずれ か火招ちつく傾向が大である。それは水る蒸気す流体で あるからである。

蒸気帶と化した地熱地に招いては, 岩盤が燒かれて粗 珪石 (珪酸質白土) となつている。これは蒸気中の硫化 水素が地表近くて酸素と化合して硫覆となり，岩盤を㢈 蝕して主として珪酸を殘留したにほかならない。

粗珪石はからて强力蒸気の噴出した所に限り必らず生 じており, 蒸気帶であつた唯一の証拠である。

粗珪石帶は過去の蒸気帶であるが, 現在るなおと括々中 К所々蒸気の噴出露頭があれば, 高温地熱地帶の有力な 証拠であり，粗珪石帶の面積が広ければ広いゲけ，また 噴出蒸気の露頭が強ければ强いだけ；呀孔により蒸気を 多く探ることができる。
地熱地帶を一見して有望か否かを決める唯一の手排り は，粗珪石の分布範围が広いかどうかということ〉，そ れに伴つて强力な蒸気の露頭があるかぞうかにある。

僅かな蒸気露頭や地温があつても, 粗珪石帶のないる のは，蒸気抢よび蒸気量を余り期待できない。た地下 水の多い地帶と同様である。

蒸気帶の立体的形狀を知ることが，地熱的究の重要な 要素の 1 つである。

完全不透気層下の蒸気を発見期待するのは，症状のな い体を病体として診察するのと同じ例である。

日本の地熱地の面積を総計して,これ和穿孔しうる数 を想像して見ると，以外飞漠大なのには驚かされる。

(昭和 28 年 4 月 19 日)

\section{文献}

奥田克已・若杉節夫・藤野勉：地樊発電の研究，昭和 23 年 9 月 26 日

奥田克己：地下に於ける天然蒸気の狀態と噴気井の特 性, 第 4 回世界動力会議論文集 昭和 25 年

実藤修作: 発電用天然蒸気に就、て, 九州工業大学学 報 第 2 号別刷 昭和 26 年 10 月

九州電力株式会社：伊太利地熱発調查報告書 1952 年 山本勝郎：噴気孔に扣ける天然蒸気の流れ，機蛲試験 昕報告 昭和 28 年 3 月

近藤信興：大分県別府に招ける地熱調查の結果火就い $\tau$, 地学雜誌 第 58 卷 4-5 号 昭和 24 年 7 月

\section{交換および寄贈雜誌・図書 (1)}

昭和 28 年 3 月 1 日以降 5 月 31 日までの交换怙よ び寄贈雜誌ならびと図書は头の如くで岁る。 日本鉱業会誌：第 69 卷第 775 号, 776, 777, 778, 等業拹会誌：第 61 集第 681 号, 682, 683, 建築雜誌: 第 68 怣第 795 号, 796, 797, 海洋時報: 第 2 卷第 12 号, 第 3 卷 1 号, 気象呼究所歐交報告: 第 3 尜第 2 号, 3,4 , 鉄々鋼: 箩 39 年第 1 号, 2,3 , 運輸技術研究所報告: 第 3 兴第 1 号, 2,3 , 科学研究所報告: 第 28 輯第 5 号, 6 ,

人交地理：第 4 卷第 6 号,

地質学雜誌：第 59 然第 689 号, 690 ,

日本化学総覽: 第 2 集第 27 卷第 2 号, 3,4 , 史淵：第 55 輯, 56 ,

東京大学敉養学部紀要：第 2 卷第 2 号,
霜科材料研究所要覽: 1952 年, 工業技術: 第 3 炝第 2 号, 3,4 , $1 / 500000$ 地質図: 福岡, $1 / 75000$ 地質図: 㴖和野, 熱海, 1/50000 地質図 : 三河大野, 茅沼, 同說明書, 立命館交学: 第 93 号, 94, 95, 96, 東北呼究: 第 3 然第 1 号, 2 , 地理学評論: 第 26 㷈第 3 号, 4,5 , 石油技術協会誌：第 18 兊第 1 号, 2 , 地理調查所歐交報告: 第 3 卷第 1 号, 日本化学者総覽: 昭和 28 年版 九州鉣山学会誌：第 21 焱第 3 号, 4 , 温泉: 第 21 卷第 4 号, 5 , 天文月報：第 46 卷第 4 号，5，6， 気像集誌: 第 2 輯第 31 卷第 2 号, 北海道地下資源調查資料: 第 1 号, $2,3,4,5,6,7$, 